University of Warwick institutional repository: http://go.warwick.ac.uk/wrap This paper is made available online in accordance with publisher policies. Please scroll down to view the document itself. Please refer to the repository record for this item and our policy information available from the repository home page for further information.

To see the final version of this paper please visit the publisher's website. Access to the published version may require a subscription.

Author(s): Ben Clift

Article Title: The New Political Economy of Dirigisme: French

Macroeconomic Policy, Unrepentant Sinning and the Stability and Growth Pact

Year of publication: 2004

Link to published version:

http://dx.doi.org/ 10.1111/j.1467-856X.2006.00235.x

Publisher statement: The definitive version is available at www.blackwell-synergy.com 
The New Political Economy of Dirigisme

\title{
The New Political Economy of Dirigisme: French Macroeconomic Policy, Unrepentant Sinning, and the Stability and Growth Pact
}

\author{
This paper appeared as 'The New Political Economy of Dirigisme: French \\ Macroeconomic Policy, Unrepentant Sinning, and the Stability and Growth Pact'. British \\ Journal of Politics and International Relations, Volume 8, Number 3 (2006), pp. 388- \\ 409. ISSN: 1369-1481. \\ Dr. Ben Clift, B.M.Clift@Warwick.ac.uk \\ Department of Politics and International Studies, \\ University of Warwick, Coventry CV4 7AL, UK.
}

\begin{abstract}
This article traces the enduring influence of the dirigiste traditions on contemporary French macroeconomic policymaking, arguing that French policy both within and towards the Stability and Growth Pact (SGP) is consistent with long-standing French dirigiste preferences and policy traditions. Specifically it explores how, within the SGP, French governments have created and defended significant fiscal policy space, and how the scope for discretionary policy-making has in fact been enhanced by the credibility accrued through European rule-based governance. Furthermore, it analyses how, in their policies towards the SGP, French governments have successfully influenced the reshaping of the fiscal policy architecture, introducing a more dirigiste interventionism in the interpretation and implementation of the SGP, loosening constraints in accordance with dirigiste preferences. French policymakers have thus played a 'long-run game’ with European economic governance - initially accepting ordo-liberal orthodoxy, only to subsequently 'move the goalposts' in a more dirigiste direction.
\end{abstract}


The New Political Economy of Dirigisme

\section{The New Political Economy of Dirigisme: French Macroeconomic Policy, Unrepentant Sinning, and the Stability and Growth Pact}

\section{Introduction}

Dirigisme denotes the French tradition of directive state intervention in economic activity. Underpinned by the Republican étatiste tradition (Hazareesingh 1994, chs 3 and 6; Dyson 1980, 27-9), state intervention in economic activity in France has been predicated upon the state conceived as 'guiding force', providing capitalism with the necessary direction. A concept central to understand such dirigiste policy impulses is the French term volontarisme. This refers to an activist, interventionist economic policy approach which places emphasis on the discretionary actions of policy-makers. The state, dirigisme assumes, should operate as an organiser and regulator of economic activity, a protector of the public sector, and as a strategic actor (Dyson 1980, 95-7; Schmidt 1996, 73-93; Schmidt 1997, 229). What flowed from this model was a presumption on the part of administrative, economic and political elites, and on the part of the wider populace, that the agencies of the French State could and should actively intervene in the economic and industrial sphere. In the second half of the $20^{\text {th }}$ Century, this dirigiste tradition of state intervention became associated with a distinctive French 'model' of capitalism allied to a 'developmental state', which sought to deliver economic growth and full employment (Zysman 1983).

The post-war French model of state-led industrial development involved an actively interventionist, dirigiste, 'player' state using its key agencies to steer the nation's economic development (Shonfield 1969, ch. 5; Hall 1986). This French dirigiste model was predicated upon a set of coordinating and steering mechanisms. The policy mechanisms included, firstly, price, credit and exchange controls. Secondly there were norms of tutelle (or hands-on supervision) over key (public and private) industries, involving 'an intricate network of commitments on the part of private firms... all in return for favours from the state... [and] the habit of the exercise of power by public officials over the private sector of the economy' (Shonfield 1969, 86 and 128). The final element was state orchestration of industrial finance through the plan. 


\section{The New Political Economy of Dirigisme}

The core macroeconomic policy-making feature of this model was the French state's inability to control the inflationary growth of credit, compounded by 'the consensual refusal of the state, the trade unions, and the employers to control nominal changes in incomes and prices’ (E. Cohen 1995, 26). Cohen has termed the resultant policy regime an 'inflationist social compromise' (1995). The macroeconomic policy elements of France's postwar dirigiste 'model' were predicated upon 'embedded liberalism' (Ruggie 1982), a regulated exchange rate international economic order, involving fairly extensive capital controls, codified at Bretton Woods. The 'competitive devaluations' and levels of state spending and state debt that this context permitted were a necessary condition of the success of France’s 'overdraft economy' (Loriaux 1991, 10-14). As that system unravelled amidst increasing, and increasingly unregulated, capital flows in the 1960s (Strange 1976; de Vries 1976), followed in the 1970s by the Nixon shock, oil crises, and further augmented liberalisation and deregulation, France's dirigiste policy paradigm came under increasing strain. International financial liberalisation rendered the dirigiste 'credit rationing' approach to monetary policy (encadrement du crédit) increasingly unworkable (E. Cohen 1996, 351).

The instinctive expectation of public direction of economic activity, and a presumption in favour of the role of the state bureaucracy steering the tiller of national economic development began to conflict with international trends towards deregulation, privatization and liberalization, not to mention stringent EU anti-trust directives. As a result, the political economy of dirigiste interventionism, and the balance between state and market that underpinned it, evolved. The French State worked increasingly with the grain of the market, with state agencies seeing their role as facilitators of the strategic restructuring of the French model of capitalism along more market-oriented lines.

In an international political economic context of the 1990s and 2000s that differs markedly from 'embedded liberalism', dirigisme is articulated in a different manner, and is more circumspect in nature. Yet this has not heralded the end of Shonfield's 'habit of the exercise of power by public officials over ... the economy' $(1969,128)$, nor the 


\section{The New Political Economy of Dirigisme}

demise directive state interventionism within the French political economy. Dirigiste and volontariste instincts and policy approaches endure, despite French government's means to direct the economy (through 'old-style' dirigisme) being reduced. The size of the French public sector remains large by comparative standards. France has the highest share of government expenditure and employment among European countries outside of the Nordic ones (OECD 2000: 62), and the public sector enjoys a peculiar importance within the French constitutional nexus (Cole 1999). Despite assertions regarding sharply reduced macroeconomic policy autonomy and the abandonment of the Keynesian paradigm as the dominant French macroeconomic policy referential in the 1980s (Lordon 2001: 116-119), the role of automatic stabilisers, and contra-cyclical budget deficits has by no means disappeared. The analysis of French fiscal policy making since the early 1990s below illustrates a considerable degree of dirigiste policy autonomy.

This article traces the enduring influence of dirigiste policy traditions on contemporary French macroeconomic policymaking, arguing that French policy both within and towards the Stability and Growth Pact (SGP) is consistent with French dirigiste preferences. Within the SGP, scope for discretionary policy-making has in fact been enhanced by the credibility accrued through European rule-based governance. Recent French governments have created and defended significant fiscal policy space, despite the context of deteriorating public finances and a slowdown across the Eurozone after 2001. Even as the French debt situation worsened, France was afforded greater margin of manoeuvre by international financial markets. Furthermore, French policymakers are playing a 'long-run game’ - challenging a prevailing Ordo-liberal (see Ryner 2003, 2037) orthodoxy stressing price stability, and the independence of monetary policy from political interference that has shaped the architecture of the Euro. In their policies towards the SGP, French governments have successfully influenced the reshaping of the fiscal policy architecture, introducing a more dirigiste interventionism in the interpretation and implementation of the SGP, and loosening constraints in accordance with dirigiste preferences. 


\section{The New Political Economy of Dirigisme}

After setting out French dirigiste preferences with regard to SGP reform, this article briefly assesses enduring volontarisme in French fiscal policy-making, interpreted here as evidence of enduring dirigiste interventionist preferences and capabilities amongst policymakers. It then explores intentional re-engineering of the supra-national fiscal policy framework of the euro in order both to expand domestic room to manoeuvre, but also as an attempt to re-articulate dirigiste policy approaches at the supra-national level.

\section{Playing a Dirigiste Long Game}

Dirigiste policy traditions are evolving in response to the changing supra-national context within which macroeconomic policy is formulated since the advent of the Euro. French policymakers pursue a dual-level dirigiste approach combining domestic volontarisme with expanding room to manoeuvre through EU-level activism (see Clift 2005). Here, competitive disinflation, and thereafter a strongly German influenced architecture of EMU are interpreted as exercises in building up necessary credibility, which French policymakers saw as a first phase in a 'long-run game' which would in turn create room to manoeuvre hopefully providing opportunities to 'move the goalposts' at a later stage (Clift 2003b).

French efforts to shift the goal posts of EMU, inserting more scope for volontarisme to counter the perceived 'monetarism' of the European Central Bank (ECB), crystallised into the proposal for an 'economic government' (EG) as a political counterweight to the ECB (Dyson \& Featherstone 1999, 172-245). These proved ultimately unsuccessful in the 1990s, sacrificed in the face of unstinting German hostility (Howarth, 2001 \& 2002). When this earlier strategy failed, the nature of the 'long-run game' French policymakers were playing with the institutions of European economic governance changed.

French policy elites found that both the political support (notably with German difficulties in meeting Pact targets) and the opportunities for something akin to the reorientations to EMU that the likes of Mitterrand and Bérégovoy had sought at Maastricht presented themselves in the years immediately following its inception in 1999. 
A combination of the credibility secured through SGP rules, and the political context of a Franco-German axis on deficit forgiveness, created areas of room to manoeuvre, notably in revising the interpretation and implementation of the SGP to align more closely with French dirigiste preferences. Thus the 'long game' French policymakers were 'playing' with European economic governance (Clift 2003b) has been successful. Policy space has been opened up, albeit not in the way anticipated, and not on the 'Euro-Keynesian' scale hoped for by some French policy-makers (Jospin 1999; 2001).

\section{The Mitterrand Experiment and Declining Fiscal Policy Autonomy}

The French case is often cited as powerful testament to the power of global finance to erode policy autonomy (Andrews 2001; B. Cohen 1996, 281; Helleiner 1994, 140-144; Halimi et al 1994). The Mitterrand era began with an ambitious 'redistributive Keynesian' (Hall, 1986) demand-boost and a dash for growth in the context of a world slump. However, within two years, a ballooning trade gap led to balance of payments problems which generated financial crises (Muet \& Fonteneau 1985). The resultant external pressures, perhaps most importantly in the form of commitments involved in staying in the European Monetary System (EMS), proved incompatible with this macroeconomic stance (Hall 1986; Cameron 1996; Lombard 1995).

One interpretation of this is the powerful 'imposition' of external constraints on French policymakers, and indeed policy-making institutions (Andrews 2001; Lordon 2001). Furthermore, some have seen this episode as an explicit challenge to the dirigiste policymaking model more broadly. The initial macro-economic policy, shifting of emphasis from redistribution and employment to a strong currency, tackling inflation and budgetary austerity, formed the springboard for an 'across-the-board assault on the dirigiste model, with reforms extending to policies and practices that had little or no bearing on the value of the franc' (Levy 2000,324). Whilst there is an element of truth in both these accounts, on closer inspection, significant qualification is required. 


\section{The New Political Economy of Dirigisme}

Firstly, it is important to note the congruence of 'external' pressures for reform along neo-liberal lines, and priorities of sectors of French policy elites, notably in the Treasury section of the Finance Ministry, and in the bank of France. Dyson insists upon the domestic as well as international origins of the prevalent economic orthodoxy, which was ultimately enshrined in the Maastricht convergence criteria. Economic and Monetary Union (EMU), he argues, 'can be seen as empowering Finance Ministry and Banque de France technocrats and rejuvenating and modernising a domestic tradition of conservative liberalism that has always been powerful in these two institutions' (1999a, 9). Secondly, the policy paradigm which emerged in the wake of the change still contained distinctive French elements, and there was still a distinctly dirigiste flavour to policy-making in certain respects. It is important to distinguish, in the French context, between neo-liberalism pur et dur and 'conservative liberalism' within the French financial and administrative elite associated with the Trésor and Banque de France.

According to Howarth, Conservative liberals 'uphold the self-adjusting nature of the market mechanisms and reject state-led reflation. They seek exchange rate stability, low inflation, balanced budgets, and commercial and balance of payments surpluses ... [and to] import German 'sound’ money policies and budget and wage discipline.' (Howarth 2002, 147) Yet French 'Conservative liberals' differ from German Ordo-liberals and Anglo-Saxon neo-liberals, notably in their attachment to a welfare state (with spending restrictions), a more equivocal commitment to free markets, and an enduring attachment to dirigiste instincts. Theirs is also a more equivocal commitment to balanced budgets, as shall be amply demonstrated in the empirical sections below.

Conservative liberals retain a somewhat Polanyian concern for some controls of free markets, recognising the potentially 'pernicious effects of a market-controlled economy' (Polanyi 2001[1944], 80). Conservative liberals share Polanyi’s reservations about the danger of subordinating 'the substance of society itself to the laws of the market' (2001, 75), and the need for the 'protective covering of cultural institutions' (Polanyi 2001, 76) to contain the fundamental contradictions inherent in the laissez-faire 'self-regulating' market system. 
French conservative liberals accordingly retain an attachment to a dirigiste state sustained by the French Republican tradition which marks them out from German Ordo-liberals, who see the social market as being secured by the social partners, rather than by the state (Ryner 2003, 206-7). As a technocratic doctrine, conservative liberalism is much more enthused by the importance, significance and relevance of the expertise of state actors in managing economic and social policy than Ordo-liberalism would normally countenance (see Howarth, 2002, 147-152; Dyson 1999a). Dyson and Howarth are correct to insist that this, rather than fully blown neo-liberalism, was the 'dominant ideology' of financial and administrative elites in France, and provided the foundations of the cognitive framework through which the preparations for the EMU project were framed. This ideational distinction did not feed through into policy differences in the short to medium term (see Clift 2003b). However, this remained a powerful undercurrent within the French macro-policy community, and it would, when circumstances permitted, reemerge.

\section{French Dirigiste Preferences for European Economic Governance}

This section sets out a number of key interventions by French policy elites to illustrate how French dirigiste preferences translate into proposals for European macroeconomic governance and SGP reform. The process of SGP reform itself will then be analysed in a later section to establish the degree of 'fit' with French preferences.

French policy-makers' engagement with what they term 'European construction' illustrates a dialectical process. Ladrech has identified within the 'Europeanisation of French Social democracy', 'both a long slow adaptation of French domestic politics and institutions to the logic of European integration (especially economic), and an intentional engineering of the EU itself to further French interests' (2001, 40). This characterisation in fact transcends the partisan divide. France under governments of both left and right have, since the onset of EMU negotiations in 1988, been trying to re-order the Euro in its own image, whilst at the same time being constrained by it (Dyson \& Featherstone 1999; 


\section{The New Political Economy of Dirigisme}

Howarth 2001). The form of this attempted re-ordering has evolved. Attempts at renegotiating the Treaty and Pact in the 1990s have been superseded by reinterpretation of the rules and their implementation in the 2000s.

In the field of French macro-economic policy, and indeed the framework within which it was created, there has been a protracted and problematic process of French adaptation to a European, or more accurately German, economic policy-making style (Dyson 1999a; Cole \& Drake 2000). French discourse and policies in relation to EU level economic governance, Howarth notes, are consistent with long standing French preferences, and rooted in the French Republican tradition (2004a, 1; see also Dyson \& Featherstone 1999, ch. 2). Calls for EG grew out of a belief that control over economic and monetary policy should not be separated, and garnered the perception - rooted in the history of French political economy- that low inflationary economic policies can be maintained by democratically elected officials, guided by enlightened bureaucrats and advisors (Howarth 2004a, 8; Dyson \& Featherstone 1999, ch. 2). These sources are directly traceable to the dirigiste traditions of French economic-policymaking, or what Shonfield called 'the habit of the exercise of power by public officials over ... the economy' (1969, 128). Indeed, careful scholarship (Howarth 2004a) has discerned no less than six distinct policy positions, rooted in different conceptions of EG. This variety is testament to the rich texture of French dirigiste policy traditions, and the power of volontariste policy reflexes.

Within these six versions of economic government, it is the 'stabilisation' function institutionalised at Maastricht and in the SGP that is so often afforded primacy in analysing the implications for domestic policy autonomy of the Euro. Gill, for example, highlights the 'rules-based economic constitution' underpinning EMU, steeped in a 'disciplinary neoliberal discourse' that has shifted the European union towards a neoliberal model of capitalism. He also correctly highlights that the 'new constitutionalism' of EMU favours ‘tight monetary and financial discipline’ and 'strict control over fiscal policy’ (Gill 1998, 9). 


\section{The New Political Economy of Dirigisme}

However, as Howarth argues, this EG as stabilisation version has always been of secondary importance within French discourse and policymaking (2004a), pushed aside by more dirigiste iterations. Thus Gill's fiscal discipline has not materialised in the predicted form. The difference of emphasis is understandable, coloured by the context in which Gill was writing, a conjuncture characterised by fiscal belt-tightening to meet the criteria exacerbated by a prolonged slowdown. However, in hindsight, the structural and inexorable character of this fiscal constraint has been overstated. As the economic conjuncture shifted, it turned out that French governments were not as tightly bound to the mast of fiscal rectitude, to borrow Gill’s analogy $(1998,18)$, as it had first appeared.

In 1997, the Jospin Government's attempts at institutional re-engineering of the supranational economic policy regime advocated a political role in the determination of exchange rates, and a balancing of stability with other economic priorities, notably employment and growth (see Clift 2003a, chs 6 \& 7). Jospin's four 'conditions' on the passage to the Euro of the 1997 election manifesto (PS 1997, 12-13) distilled the diverse elements of the dirigiste EG aspirations of French Socialists. Notably, Jospin insisted that, next to the ECB, there must be established 'a European economic government, representing the people and charged with co-ordinating the economic policies of the various nations.' Jospin further argued that 'Europe must be social and political,' therefore, 'we want the relations between participating Euro countries to be founded not on an austerity pact [an explicit reference to the German inspired SGP], but on a solidarity and growth pact, permitting policies in favour of job creation and social cohesion’ (PS 1997, 12-13).

In April 1999 Dominique Strauss-Kahn, then Finance Minister, offered a further iteration of dirigiste French preferences in relation to the SGP and economic government. The euro, he argued, 'should make us more autonomous in the conduct of our economic policies', and this autonomy should be directed towards the 'political priority' of employment and growth (Strauss-Kahn 1999). 


\section{The New Political Economy of Dirigisme}

Strauss-Kahn championed the political role of the Eurogroup, an informal structure bringing together the Ministers from Ecofin (the Council of EU finance and economy Ministers) that represent euro area Member States. Strauss-Kahn afforded the Eurogroup a key role in the 'implementation of Europe's policy mix' geared towards growth and job creation. The 'Euro-11 has taken up an essential role in strengthening co-ordination of economic policies, including fiscal policies, within the euro area', indeed, Strauss-Kahn claimed 'Euro-11 is the precursor of a European economic government'. Specifically, Strauss-Kahn argued 'Fiscal policies, within the framework of the Stability and Growth Pact, should promote strong and sustainable growth, especially in the event of a sharp drop in activity. This assumes that we accumulate enough room for manoeuvre during periods of high economic growth so that automatic stabilisers can be allowed to act when the economy slows down'. The aim was to 'enable automatic stabilisers to play their full part ... [making] fiscal policy an instrument for smoothing out ups and downs in the economy without compromising objectives for correcting structural deficits' (StraussKahn 1999; see also Mathieu \& Sterdyniak 2003, 172).

The combined efforts of Jospin's chief economic advisor Pisani-Ferry and then EU Trade Commissioner Pascal Lamy further elaborated dirigiste Euro reform proposals (Lamy \& Pisani-Ferry 2002; see also Pisani-Ferry 2002). They criticised those who advocated 'a Europe constructed on rules and procedures, whose ideal model of the world seems to be one in which there would no longer be a need to make discretionary decisions' (2002, 51). Characterising the ECB inflation target of a price increase of between 0 and 2 per cent as 'inappropriate' (2002, 110), they noted 'while the Americans have given an equal weighting to monetary stability and growth, the Europeans have decided to give their central bank the narrow task of ensuring price stability’ $(2002,109)$.

Pisani-Ferry and Lamy advocated 'a more French model', 'based on an institutionalized dialogue [between the ECB and] the political authorities (Eurogroup and Council)' (2002, 111), a strengthening of the Eurogroup (2002, 116), and an enhanced role for the ECB board, 'whose role in decision-making and the dialogue with the political pillar (especially the Eurogroup) are essential' (2002, 112). Seeking the abandonment of the 


\section{The New Political Economy of Dirigisme}

ECB's existing inflation target 'in favour of a symmetrical target for inflation, expressed as a range of, say, 1 to 3 per cent' $(2002,111)$, they proposed 'operational independence based on the British model which would, for example, give the Eurogroup the right to set (on the basis of a Commission recommendation) the price inflation objective' $(2002,112)$

The dirigiste justification for these reforms is that 'Economic policy does not boil down to a collection of disciplines and rules of good conduct ... there are times when it is necessary to have the ability to decide and act' $(2002,114)$. To this end Pisani-Ferry and Lamy sought 'definition of principles of economic policy for the euro zone .... [which would] detail how to use economic policy instruments in times of unexpected shocks, and discuss the proper management of budgetary policy in order that it retain its role as an instrument of national economic policy’ $(2002,115)$.

Each instance involved a dirigiste and volontariste approach to European economic governance in general, and fiscal policy-making in particular, and an emphasis on discretion of national economic policy-makers over EU-level rules. The mooted balancing of stability with other economic priorities, notably employment and growth, was alien to traditional German 'ordo-liberal' monetary arrangements. This represents a re-emergence of much of the French agenda from the Maastricht discussions, and a desire to flex dirigiste muscles in order to pull macroeconomic policy levers in the face of low growth, slowed down by mass unemployment, and in the mid 1990s, prohibitive interest rates (see e.g. Moscovici 1997, 58). Dyson notes that the French Socialists in particular 'sought to draw a line between embracing rules of 'sound' public finance and money and taking on the whole apparatus of neo-liberal and monetarist policy discourse' (1999b, 202). The aim was for a negotiated rebalancing of the policy mix, notably carving out a role for a fiscal policy geared towards growth.

\section{Using the 'Policy Space': Domestic volontarisme}

Assessment how these dirigiste preferences underpinned the supra-national element of France’s dual-level dirigiste strategy will be contextualised with a brief discussion of 


\section{The New Political Economy of Dirigisme}

recent French fiscal policy (see also Clift \& Tomlinson 2004, 522-26). In the early 1990s, the Socialist Government tackled recession through a decidedly dirigiste counter cyclical expansionary fiscal policy, which saw the public deficit rise to unprecedented levels. Despite subsequent harsh fiscal consolidation, in a gesture that demonstrated French policy-makers' desire for autonomy, and the uneasy acceptance of the rules-based regime, France alone amongst EMU participant countries officially failed to respect the deficit target for 1997 (the Government figure was 3.1 per cent). Yet this official breach contradicted authoritative indications that the deficit criterion had been met (OFCE 2000, 65). ${ }^{1}$

From 1998 onwards, the fruits of economic growth generated more room to manoeuvre, and public spending accelerated in 1999 (+2.4 per cent in volume, compared with average of 1.2 per cent between 1993 and 1997) (Dupont 2001, 63-5). The extent to which French fiscal policy was directed at the Jospin Government's employment and redistributive priorities illustrates the enduring dirigisme of French governments (see Clift 2001; Howarth 2002, 150; Cole \& Drake 2000). Purchasing power as a proportion of household revenue increased by 16 per cent between 1997 and 2002 (Clift 2003a, 159161). The fruits of growth were used to embark, in 2000, on the biggest tax cut in 20 years. All of this saw deficits rise, particularly as growth faltered in 2001. The breach of the 3 per cent deficit ceiling, compounded by perceived squandering of the fruits of growth, began to incur the wrath of the European Commission.

The degree of policy autonomy, both in the early 1990s and a decade later, is considerable, and gives the lie to the supposed tight constraints of a neoliberal EMU straitjacket (Gill 1998). French governments have clearly taken a sanguine view of future debt conditions and present deficit constraints. A degree of fiscal policy autonomy is further demonstrated in relation to where the tax burden falls in France. Swank has demonstrated (2002) that the mooted shift of the fiscal burden from more mobile capital to less mobile labour in the wake of increased capital mobility has been greatly exaggerated. The European Commission has also noted that capital's tax burden has remained broadly stable over the last three decades (European Commission 2000, 67). 


\section{The New Political Economy of Dirigisme}

The policies of the Jospin government 1997-2002 provide partial corroboration of this point. The period after 1983 had seen a marked shift in the tax burden increasing taxation on labour, and reducing it upon capital. However, after 1997, there was a marked reversal of this trend. ${ }^{2}$ While the tax burden of earners (particularly lower earners) was lessened, the Jospin Government introduced a 15 per cent tax on profits in 1997, reduced to 10 per cent in 1999, and replaced, in 2000, by a contribution sociale on profits to part finance reduced social charges of lower earners. Furthermore, a number of exemptions and tax breaks for firms were removed (Dupont 2000, 68-9).

The role of automatic stabilizers clearly retained their importance within the French fiscal policy framework (Strauss-Kahn 1999; Clift \& Tomlinson 2004). In addition to allowing the free play of automatic stabilisers, French governments have also been more explicitly dirigiste, taking discretionary measures to support growth and employment over and above the automatic stabilisers. The starkest examples of activist employment policies came under Jospin’s Socialist Government (Clift 2003a, 166-175). Amongst these, the 35-hour week stands out as a slight return to the 'heroic' policymaking style of earlier dirigiste French governments (Schmidt, 1996, 50-55). The estimated 110bn franc cost of the policy was met through a mixture of 'cost-shuffling' and increased public debt (Levy 2001, 204).

The dirigiste instincts to exploit and indeed expand policy space continued under Raffarin’s Centre Right Government form 2002 onwards. France’s sharply expansionary fiscal policy in 2002 (Clift \& Tomlinson 2004, 525) gave way to a slightly restrictive stance in 2003. That said, French Government deficit forecasts had to be repeatedly revised upwards (OFCE 2004, 8), and fiscal policy in 2004 proved less restrictive than both the stability plan, and indeed the Budget had predicted (OFCE 2004, 6-7). ${ }^{3}$ Health Minister Philippe Douste-Blazy claimed health insurance reform plans would save 3.5 bn euros by $2007^{4}$ by reducing the government's burden through increasing co-payment for doctors and hospital visits, substituting generic drugs for brand name drugs, and introducing a primary care physician as a 'gatekeeper', ending self-referral to multiple doctors and specialists (see Levy 2005: 186). The Government felt such a restrictive 


\section{The New Political Economy of Dirigisme}

budgetary measure could damage growth and dampen the economic recovery (Sterdyniak 2004, 8), and accordingly delayed reforms, clearly perceiving an absence of tight fiscal constraint. Furthermore, the Finance Ministry predicted that Douste-Blazy's reforms introduced in June 2004 were set to fall short of the savings promised to Brussels in the 2003 stability plan. ${ }^{5}$ Indeed, despite difficult public finance conditions, and Commission pressure, French fiscal policy has remained surprisingly unrestrictive. Interventionism to support economic growth is, it appears, a powerful policy reflex.

The costs of the new political economy of dirigisme are considerable, particularly when a generous welfare system predicated on social insurance assuming full employment coexists with prolonged high long term unemployment (Palier 2002). Government debt rose from 20 per cent of GDP in 1980 to 64 per cent of GDP in 2004. Yet the dirigiste policy arsenal provides ways of enabling ongoing and costly interventions to be pursued (in the dirigiste faith that such interventions are beneficial to France's economic prospects, and thus the fruits of future superior economic growth will in time repay current spending). Specifically, the restructuring of French capitalism in the late 1990s and early 2000s proved a valuable means of bank-rolling interventionist measures in the late 1990s and early 2000s. Given the draw on the public purse of debt servicing, tax cuts, and delayed spending reductions, receipts from the Government's privatisations programme provided a valuable source of income - (50 billion francs per year between 1997 and 1999), which also helped contribute to and social spending priorities (Clift 2003b; 2004). This episode is eloquent testimony to how the traditional dirigisme with which this article began is on the wane.

However, this very process of drawing back from old-style dirigisme opens up opportunities for dirigiste instincts to find their expression in different contexts and novel forms. The 3 per cent of GDP deficit target may well be met for $2005 .{ }^{6}$ However, this is certainly not solely due to fiscal prudence, nor unexpectedly strong growth in 2004. It results more directly from the payment of 7,7 billion euros to the Treasury by EDF-GDF in return for the state taking on their pension obligations. ${ }^{7}$ By such means are French governments able to square the circle of using often expensive dirigiste policy levers to 
manipulate the French economy, whilst at the same time avoiding so significant a deterioration of public finances as to generate a crisis.

\section{The Political Economy of French Fiscal Policy and the SGP: Constrained discretion, or discreet latitude?}

Turning now to the supranational institutional re-engineering element of France's dirigiste dual-level strategy, the rationale underpinning the SGP must be briefly set out. The SGP reflects concerns, particularly heightened amongst the sound money and finance policy elites at the core of the construction of EMU, that within monetary union individual national governments would face looser constraints, and temptations to 'free ride'.

This, it was feared, could potentially lead to damaging spillover effects from national policies to the wider Eurozone (see e.g. Clift \& Tomlinson 2004, 520-22; Eichengreen and Wyplosz 1998; Eijffinger and Hahn 2000, 81-87). Spillovers could arise because with a fixed exchange rate, national government borrowing would no longer involve any exchange rate risk, assuming continued adherence to the Euro. Three main elements were put in place to limit 'bad behaviour' by national governments in the context of EMU. First, there is the 'no bail-out' rule, indicating to financial institutions lending to individual governments that such lending would be guaranteed by the Union as a whole. Second, there are limits on bank holding of government debt to prevent excessive monetising of the debt and the risk that excessive borrowing could threaten the stability of financial institutions (Crawford 1996, 304 -307). Finally, there is the SGP with its rules about the fiscal policies of individual governments. ${ }^{8}$

The SGP reflected a German-led insistence on a tough regime, re-asserting not only the 3 per cent deficit and 60 per cent debt ceilings, but also inserting a medium-term aim of a budget 'close to balance or in surplus'. The Pact obliges governments to submit an annual stability programme setting out how these medium-term targets will be met. Only in exceptional circumstances (initially defined in terms of depth of a recession) are deficits 


\section{The New Political Economy of Dirigisme}

allowed to exceed 3 per cent. If the rules are breached sanctions and financial penalties may be applied (Eijffinger and Hahn 2000, 87-9).

French macroeconomic policy thinking, as has been seen, was always more equivocal about the 'sound money and finance' agenda which inspired the Pacts's rules. Attempts to rebalance the relative importance of acceptance of the German model in the pursuit of 'sound money' with more familiar, French dirigiste elements have been most consistently and successfully pursued in relation to the SGP. Juppé had begun the reorienting process at the Dublin European Council back in 1996, with the (cosmetic) insertion of the word growth. Under the Jospin and then Raffarin Governments, the reorientations would take on a much more concrete and politically and economically significant form. As the economic slowdown which began in 2001 drew on, the 'long game' French dirigiste policymakers had been playing with EMU began to bear fruit. The credibility-bolstering rules-based regime and the earlier fiscal consolidation generated policy-space which was exploited, heralding a period of 'unrepentant sinning' (in the eyes of the European Commission) on the fiscal policy front.

Since 2003, there has been a pervasive assumption of the absence of harsh constraint, permitting the delaying (in relation to health insurance) or ongoing avoidance (in relation to pensions and civil service staffing levels) of tough spending reduction decisions (see e.g. Howarth 2004b, 209-220). This should be seen in the context of a dual-level strategy seeking to enhance dirigiste room to manoeuvre. The strategy involves various means of attenuating the supranational constraint, including the presenting of optimistic growth forecasts within the context of SGP-stipulated stability plan which assume away the need for politically difficult spending cuts, and speaking duplicitously to domestic and European audiences about proposed tax cuts (Clift \& Tomlinson 2004; Howarth 2004a).

Despite (or quite possibly because of) these efforts, the Commission became increasingly antagonistic towards France. In September 2002, the then European Commissioner for Economic and Monetary Affairs Pedro Solbes noted that France was unlikely to meet the budget balance target by 2004, and called for stringent efforts to rein in public finances, 


\section{The New Political Economy of Dirigisme}

reducing the structural budget deficit by 0.5 per cent per year (Solbes 2002). France, however, refused to endorse the Commission's deficit reduction proposition. France's September 2002 SGP stability plan, and French Budget plans for 2003 (based upon decidedly optimistic growth forecasts), announced the day after Solbes' rebuke, did not conform to the budget balance requirements by 2004, nor even by 2006. France’s fiscal stance, sharply expansionary in 2002, became only slightly restrictive in 2003, and was neutral in 2004. France thus remained an 'unrepentant sinner' (Mathieu \& Sterdyniak 2003, 154 \& 159; Creel et al 2002).

The Commission decided, in May 2003, to initiate excessive deficit proceedings against France (and Germany). This created the conditions in which the French tradition of seeking to re-engineer European economic governance in a more dirigiste manner at key EU meetings reached its zenith, at the Ecofin meeting of $24^{\text {th }}-25^{\text {th }}$ November 2003 . Here, exploiting the Franco-German axis, the French and German Governments managed to secure the 'freezing' of the Excessive Deficit Procedures. This was against the expressed wishes of the Commission and the less vocal desires of a number of Euro member countries. In the wake of the Ecofin meeting of November $25^{\text {th }}$, the SGP was in disarray. This created a political crisis for the EU, not least because of the founding assumption of the SGP that the Germans would be the model of fiscal rectitude (Dyson 1999a). ${ }^{9}$

\section{SGP Reform: French policy-makers playing, and winning, the 'long-game'?}

The 1990 rules that evolved into the SGP have been subject to substantial debate. While most commentators have accepted the need for fiscal discipline, much ink has been spilt assessing the appropriate measure of fiscal prudence, and whether these specific rules made sense. Many commentators criticised the SGP as arbitrary: the crude deficit rule, for example, made no allowance for the state of the economic cycle, while the debt rule did not address under what conditions debt becomes unsustainable. Article 104 of the Maastricht Treaty specified analysis of the role of public investment within the deficit, and the taking into account of the economic cycle, and the medium term budgetary position (Mathieu \& Sterdyniak 2003, 148). However, as the process of building the 


\section{The New Political Economy of Dirigisme}

institutional architecture progressed through the 1990s, these cyclical and qualitative assessment aspects of Article 104 were largely forgotten.

In the late 1990s, the rules were seemingly being accepted by national governments, even if some had to be cut considerable slack (in terms of permitted creative accounting) in order to enter the Euro. However, with the slowing down of the European economies from 2001, many felt the rules were too restrictive, especially as most Euro zone governments started with significant structural deficits (i.e. deficits not caused by the cycle). As always, slow growth (and even more, recession) worsens the fiscal position and generates political objections to tight fiscal rules. In this case the problem was exacerbated by the ECB's slow response to the slowdown, forcing fiscal policy into a more expansionary form (Allsop and Artis 2003, 12-16).

Within a wide-ranging critique of the rules' economic justification (Mathieu \& Sterdyniak 2003), focus has centred on the 3 per cent rule, whose breach triggered the crises of 2002 and Autumn 2003. When, in October 2002, the President of the EU Commission Romano Prodi called the SGP 'stupid’ because it restricted counter-cyclical policy at a time when there appeared no threat of inflation, which was fundamentally the

problem the rules were supposed to combat, ${ }^{10}$ this ensured that SGP reform would remain high on the agenda. A year before the open crisis of the SGP the Commission began to publish its reform agenda. This was a recognition of the 'cognitive gaps' (Dyson \& Featherstone 1999, 784-6) and flaws in the original EMU framework, for example the need to allow the free play of automatic stabilizers, without straitjackets of tight deficit rules insensitive to the economic cycle, or economic circumstances.

The Commission's November 2002 proposals, while re-affirming the medium-term balanced budget rule, did recognise some of the problems with the SGP. They suggested inter alia that the balanced budget rule needed to be linked to the economic cycle; that countries should not pursue pro-cyclical policies during periods of growth (so reducing their room for manoeuvre in the downswing); and that the overall health of the economy, and the sustainability of its debt levels should be taken into account in judging a budget 


\section{The New Political Economy of Dirigisme}

deficit (Begg, Hodson, and Maher 2003, 74-6). Whilst dangling such carrots, the Commission continued to wield the stick against France and Germany by taking its case against the holding in abeyance of the excessive deficit procedures to the European Court of Justice (ECJ) in early 2004. The ECJ ruling of 13 July 2004 found in favour of the Commission and 'annulled' the excessive deficit procedure suspension (European Court of Justice 2004). ${ }^{11}$ This heightened the need for a consensus position between Ecofin and the Commission to diffuse the open warfare between the Commission and France and Germany.

The key elements of such a consensus had in fact been part of the reform debate under discussion within the relevant EU institutions for some time (Ecofin 2003; European Commission 2002 \& 2004a). For example, in November 2002, and again in July 2003 (when Chirac called for softening of the Pact ${ }^{12}$ ), then Finance Minister Francis Mer called for a reformed SGP to explicitly take into account new criteria, including inflation and levels of unemployment, and not longer be exclusively focused on deficits. French preferences continued to emphasise growth, and in September 2004 Mer's successor Sarkozy re-affirmed the desire for the explicit objectives of 'employment and the return of growth' to be part of a revised pact. ${ }^{13}$

This position began to solidify with the June 2004 European Council's call to strengthen and clarify the implementation of the SGP. The Commission sought to influence the shape of SGP reform (ultimately to be decided by the Council), publishing Strengthening economic governance and clarifying the implementation of the stability and Growth Pact (European Commission 2004a). Significantly, the emergent consensus is largely aligned with French preferences, notably in taking more account of specific national conditions in assessing deficits and debt, and in focusing more on the avoiding the potentially adverse impact on growth of a rigidly and restrictively interpreted SGP. Indeed, the French Finance Minister Sarkozy welcomed the Commission proposals as 'moving in the right direction.' 14 


\section{The New Political Economy of Dirigisme}

The 3 per cent reference value for the deficit to GDP ratio and the 60 per cent debt to GDP remain the 'nominal anchors' of the Pact, but in both its 2002 and 2004 proposals, the Commission recognised 'a uniform medium-term target for all countries does not appear to be appropriate ... [thus] we can enhance the credibility and enforceability of our fiscal framework by emphasising the economic rational of the Pact, by taking better account of economic fundamentals' (Almunia 2004, 3). The 'revised approach' (European Commission 2004a: 3) addresses explicitly 'how the instruments for EU economic governance could be better interlinked in order to enhance the contribution of fiscal policy to economic growth '(European Commission 2004a, 2). That this refrain recalls the volontarisme characteristic of French dirigiste approaches to macroeconomic policy, and could have been taken from a speech by Bérégovoy or Mitterrand in the early 1990s, illustrates the fruits the 'long game' has borne.

Although the Commission remained opposed to greater flexibility, the implications of its own guidelines are a more flexible, and cyclically attuned Pact (European Commission 2004a: 4). French dirigiste desires for more political interpretation and discretion in applying the Pact's rules are substantially realised. The Commission introduced interpretive caveats including 'allowing for more country-specific circumstances in defining medium-term objectives of "close to balance or in surplus", (European Commission 2004a, 3). It also envisaged accepting a slower pace of debt reduction if growth rates are below potential, and sought to ensure, within SGP interpretation, 'sufficient room to manoeuvre of the budget deficit to avoid breaching the 3 per cent reference value during an economic slowdown without recourse to pro-cyclical fiscal policy.’ (European Commission 2004a, 4)

French policy-makers' key role in finalising the actual reforms to the Pact implementation strategy which culminated at the extraordinary Ecofin meeting of March $20^{\text {th }} 2005$ (Ecofin 2005), helped ensure a dirigiste approach, with interpretation by elected politicians to the fore. Subsequently affirmed by the European Council meetings of March $22^{\text {nd }}$ and $23^{\text {rd }} 2005$ (European Council 2005), the French dirigiste refrain about 


\section{The New Political Economy of Dirigisme}

enhancing the contribution of fiscal policy to economic growth also found its way into the SGP implementation reform document (Ecofin 2005, 22).

In a direct accommodation of French (and German) preferences, the Commission had contemplated 'widening the definition' of the exceptional circumstances clauses that permit breach of the 3 per cent deficit target (European Commission 2004a, 5). The March 2005 Ecofin document explicitly states that original interpretations of severe economic downturn as 'exceptional and temporary' circumstances which justify breaching the reference targets were 'too restrictive', and that a revised interpretation should include 'accumulated loss of output during a protracted period of very low growth relative to potential growth' (Ecofin 2005, 33). This political (re-)interpretation of the conditions under which the excessive deficit procedures are to be initiated is precisely what successive French Finance Ministers had argued for between 2002 and 2004. French policymakers sought successfully to avoid any automatic mechanism triggering the procedures being retained in the revised Pact. At a meeting of Finance Ministers to discuss that revision in February 2005, French Finance Minister Hervé Gaymard argued for 'economic policies decided by elected ministers' to prevail over 'a pre-established auto-pilot'. 15

Also consistent with French dirigiste preferences, Ecofin's new implementation strategy for the SGP involved a 'higher degree of economic judgement and policy discretion in the surveillance and coordination of budgetary policies' (Ecofin 2005, 22), further enhancing role and significance of elected politicians, in part through the Eurogroup. French aspirations for a strengthening of the Euro-group had previously received a boost with the agreement to elect a leader of the Euro group as of January 2005. Sarkozy welcomed the selection of Luxembourg's Prime Minister Jean-Claude Junker as the first 'Mr. Euro', 'Europeans will now understand that there is economic government in Europe'. ${ }^{16}$ Whilst this betrays a French tradition of 'talking up' the Eurogroup, it was nevertheless significant that Juncker, head of the Eurogroup, was also head of the Presidency of the European Union as the crucial SGP implementation strategy reforms were finalised. 


\section{The New Political Economy of Dirigisme}

One recurrent issue in the reform debate between 2002 and 2005 relates the SGP's 'asymmetry' problem (Mayes \& Viren 2004, 783), namely its failure to constrain governments to repay more debt during upswings. In 2002, the Commission raised this issue in relation to excessively expansionary French fiscal policy (Mathieu \& Sterdyniak 2003, 159). The original model of the pact seeks to cut deficits and debt loads to increase room to manoeuvre for governments over time. Possibly recognising the merits of the long-term room to manoeuvre arguments, Jospin's advisor recognised the need to tackle 'insufficient constraint on lax fiscal policies in good times’ (Pisani-Ferry 2002, 2). The Raffarin Government was less convinced (Howarth 2004a, 29-31). The final version of Ecofin's the SGP implementation reform document contained an exhortation that 'periods of growth should be used for budgetary consolidation' (Ecofin 2005, 28), but contained no specifics or sanctions. This section included numerous qualifications about the need for 'room to manoeuvre', and for an approach to the medium term objective (close to balance or in surplus) 'differentiated for individual member states to take into account the diversity of economic and budgetary positions and developments as well as the fiscal risk to the sustainability of public finances' (Ecofin 2005, 28-30). These caveats undermine any constraining effect this section of the revised Pact implementation strategy might otherwise have.

French dirigiste preferences favoured a more differentiated approach to deficits, notably which aspects of public expenditure are included in deficit calculations. This idea was mooted by Mer in June 2002 when he said in a TV interview that the SGP was 'not carved in marble', and that 'the content of the Pact, particularly in relation to investment ... can be to large extent revisited'. ${ }^{17}$ These calls for a differentiated assessment of government spending, affording 'strategic' spending - variously defined as research (because it promotes future growth), infrastructure, education, and defence - a special status and excluding it from deficit calculations were reaffirmed in early $2005 .{ }^{18}$ As Prime Minister Raffarin put it, 'spending with strategic European implications must have a particular status'. 19 


\section{The New Political Economy of Dirigisme}

This most ambitious dirigiste manoeuvre to loosen fiscal constraints, which some calculate would effectively shift the deficit target to 6.5 or even 7 per cent of GDP

(Mathieu \& Sterdyniak 2005), did not succeed in anything like its maximalist form, ${ }^{20}$ and the 'redefinition of the Maastricht [deficit] reference value ... via the exclusion of particular items' was explicitly rejected (Ecofin 2005, 34). Yet it finds its way, in amended form, into Ecofin's SGP implementation document, which notes that, 'in order to enhance the growth oriented nature of the Pact', certain structural reforms 'which have direct long-term cost-saving effects, including raising potential growth’ may be ‘taken into account' when defining the 'path of adjustment' (Ecofin 2005, 30-31). Furthermore, 'policies to foster R\&D and innovation' and 'public investment and the overall quality of public finances' are both explicitly mentioned amongst the 'other relevant factors' to take into account before deciding upon beginning excessive deficit procedures (Ecofin 2005, 34). On those areas less favourable to French preferences, notably pressure to cut deficits by 0.5 per cent if the medium term target is not met, the absence of enforcement mechanisms is conspicuous.

In the crucial area of enforcement of excessive deficit procedures, even a Commission opposed to explicitly recognising greater flexibility conceded that 'one-size-fits-all deadlines for the correction of excessive deficits ... can lead to erroneous policy advice for instance asking for too stringent pro-cyclical adjustments' (European Commission 2004a: 5). As French policy elites had long been advocating, more account is now taken of country-specific 'cyclical developments', debt levels, and 'the economic conditions and fundamentals of a Member State breaching the 3 per cent reference value.' (European Commission 2004a, 5). Ecofin’s March 2005 revisions echo French preferences for greater focus on debt levels, dynamics and sustainability, noting ' $[\mathrm{t}]$ he higher the debt to GDP ratios of Member States, the greater must be their efforts to reduce them rapidly' (2005, 35). The revised implementation of SGP strategy agreed by Ecofin also lists a range of 'other relevant factors' to be considered before pursuing excessive deficit procedures. Ecofin's new approach will give due consideration 'to any other factors, which in the opinion of the Member State concerned, are relevant in order to comprehensively assess in qualitative terms the excess over the reference value' (Ecofin 


\section{The New Political Economy of Dirigisme}

2005, 34). This has the effect of increasingly the flexibility of the Pact that some, including the Commission, were trying to avoid.

In terms of the time horizons for a return to meeting the 3 per cent rule, consistent with the Commission's earlier recommendation to extend France and Germany’s deadline for correction their 2002 excessive deficits from 2004 to 2005, Ecofin's revised implementation strategy envisages a possible lengthening. '[I]n case of special circumstances,' the report notes, 'the initial deadline for correcting an excessive deficit could be set one year later, i.e. the second year after its identification and thus normally the third year after its occurrence' (Ecofin 2005, 37). This evolution meets a longstanding French demand reaffirmed in January 2005. ${ }^{21}$ 'If,' the then French Finance Minister Sarkozy noted wryly in September 2004, 'the return under 3 per cent is too brutal, there is a risk of dying from the cure'. ${ }^{22}$

The Commission emphasises member states' 'peer pressure' enforcement through 'naming, shaming, and if necessary blaming' (European Commission 2004a, 8). Given the experience of November 2003, French policy elites are confident that this will present little manifest constraint. The increased emphasis on sustainability of public finances, in the current low interest rate context (see Clift \& Tomlinson, 2004), also represents a softening of constraints for many states. French policy-makers continue to champion a 'political' reading of fiscal rules in keeping with volontariste and dirigiste policy traditions. Consistent with these preferences, the string of qualifications, combined with the difficulties of measuring the medium term balances accurately have shifted the SGP more clearly onto the territory of 'soft' law, and make enforcement and decisions about breaches more politically difficult to arrive at (see Howarth 2004a, 30-32).

In December 2004, the commission published a communication to the European Council assessing France and Germany's situation in relation to the excessive deficit procedures initiated in 2003, and re-activated after the July 2004 ECJ ruling. The Commission raised concerns about the vulnerability of France's budgetary position, questioning levels of saving from Health insurance reform, and the one-off payment from EDF-GDF, likely to 


\section{The New Political Economy of Dirigisme}

increase liabilities in the long run. Nevertheless, the Commission concluded that, since France was set to meet the 3 per cent target in 2005, 'no further steps are necessary at this point under the excessive deficit procedure' (European Commission 2004b, 7). Thus French policy elites have successfully played a long-run game, signing up to the establishment tough rules to build credibility, then using the policy space so created to pursue policies which might otherwise be unsustainable. Subsequently, in relation to the SGP, French policymakers have also begun to engage in a revision of those rules to introduce greater interpretive flexibility, again without any demonstrable adverse effects on credibility.

\section{Conclusions}

So solid have been the ordo-liberal sound money and finance foundations of the EMU project, and the prevalent perceptions arising from them, that French governments have been able to attenuate, indeed neglect, budgetary rigour, without a loss of confidence and credibility (or low interest rates). Even the shift from 'hard' co-ordination to an altogether 'softer' SGP enforcement and interpretation regime has not demonstrably damaged the credibility of French governments. ${ }^{23}$

The virtues of sound money and sound public finances remain a priority - but they have been set in the context of other priorities, and the potential for conflicts and trade-offs between them has been recognised as has the need to allow the free play of automatic stabilizers, without straitjackets of tight, deficit rules insensitive to the economic cycle, or economic circumstances. Credibility could be retained whilst breaching (for 'sound' economic reasons given the economic conjuncture) the rules. The 'long-run game' has borne fruit in terms of enhanced policy autonomy. France's budgetary policy, whilst less expansionary than 2002, has not become restrictive. Aided by stronger growth than many had anticipated, and some dirigiste creative accounting, France has successfully diffused the Commission's antagonism without effective constraint being wielded upon its activist, growth-oriented fiscal policy. 


\section{The New Political Economy of Dirigisme}

Not only has the existing SGP not proved a manifest constraint on French, or indeed other Eurozone countries fiscal policy-making in the last few years, but furthermore, the Franco German alliance on tax cuts and deficit growth has shifted the terms of the reform debate decisively in favour of the kind of dirigiste reorientations long-desired by French policymakers. The new iteration of SGP is much more attuned to French preferences, demonstrating the success of the 'long run game' French policymakers have played in relation to the fiscal rules of EMU. Whilst untrammelled fiscal recidivism would doubtless damage the credibility of the Euro, with impacts on currency and bond markets, clearly the judgement of actors in financial markets suggests that the SGP's falling into abeyance, and France enduring (although, more recently, curtailed) 'unrepentant sinner' status has not brought us close to that threshold. In macroeconomic policymaking, French policymakers' dual-level strategy has successfully carved out dirigiste policy space at the domestic and supra-national levels.

\footnotetext{
${ }^{1}$ Meeting (or narrowly missing) the 3 per cent reference target in time for accession to EMU involved a certain amount of creative accounting - notably with France Telecom's payment of 45 billion francs to the French state in return for the state taking over future pension obligations (OFCE 2000: 65).

${ }^{2}$ The boost in government tax take as growth kicked in was in part due to 22.6 per cent rise in company profit taxation.

${ }^{3}$ Those seeking to explain the unexpectedly healthy (2.2 per cent) growth performance of the French economy in 2004 point in part to the non-restrictive fiscal policy.

${ }^{4}$ Le Monde, 'Assurance-maladie : Bercy et le ministère de la santé divergent sur l'impact du plan', 25 June 2004

${ }^{5}$ Le Monde, 'Assurance-maladie : Bercy et le ministère de la santé divergent sur l'impact du plan', 25 June 2004

${ }^{6}$ Although the IMF remain sceptical about this prospect, 'France-2005 Article IV Consultation Concluding Statement of the Mission’ 11 July 2005, http://www.imf.org/external/np/ms/2005/071105a.htm accessed 10 November 2005. ${ }^{7}$ Le Monde 'La soulte d'EDF-GDF permet à M. Sarkozy d'afficher un déficit inférieur à 3 per cent du PIB en 2005’, 25 September 2004.

8 The core commitment of the Stability and Growth Pact, is to fiscal discipline and stabilization. It commits states to the '... medium-term objective of budgetary positions close to balance or in surplus...' which '... will allow Member States to deal with the normal cyclical fluctuations while keeping the government deficit within the 3 per cent [of GDP] reference value'. Formally, the Pact consists of three elements:- preventive elements which through regular surveillance aim at preventing budget deficits going above the 3 per cent of GDP; dissuasive elements which in the event of the 3 per cent
} 
level being breached, require Member States to take immediate corrective action and, if necessary, allow for the imposition of sanctions. Lastly, it involves a political commitment by all parties involved in the Pact (Commission, Member States, Council) to the full and timely implementation of the budget surveillance process. (European Commission 2000: 45-7).

${ }^{9}$ Interestingly, the impact on the financial markets of this open crisis of the institutional framework of EMU, which the newly appointed governor of the ECB, Jean-Claude Trichet warned was a grave danger for the credibility of the Euro, was negligible. Indeed, the collapse of SGP coincided with the highest ever value of Euro to dollar, at the end of a 16 per cent appreciation in 2003. Indicating actors on financial markets continue to have confidence, long term interest rates. Long-term French sovereign bond rates rose slightly from 4.33 to 4.44 (Le Monde, 1 December 2003) - but this was simply a fluctuation, and there is no indication of any discernable effect on costs of borrowing.Banque de France Bulletin Digest, Nos. 121-123, January- March 2004.

${ }^{10}$ Financial Times 'Prodi says euro rules are 'stupid', 18 October 2002

${ }^{11}$ Le Monde, 'Pacte de stabilité: la justice européenne condamne Paris et Berlin’, 13 July 2004.

${ }^{12}$ Le Monde 'Déficits publics : plusieurs pays de l'Union disent « non » à Jacques Chirac', 16 July 2003.

${ }^{13}$ Le Monde 'Les Européens s'accordent sur la future réforme du pacte de stabilité', 13 September 2004.

${ }^{14}$ L'Expansion, 'Jean-Claude Junker, premier "Monsieur Euro"' 10 September 2004.

${ }^{15}$ L'Expansion 'La France et l'Allemagne contre une "réformette" du pacte de stabilité' 17 February 2005

${ }^{16}$ L'Expansion, 'Jean-Claude Junker, premier "Monsieur Euro"' 10 September 2004.

${ }^{17}$ La Tribune 'Francis Mer sème le trouble sur le Pacte de stabilité', 7 June 2002.

${ }^{18}$ Libération 'Hervé Gaymard se remet dans l'axe franco-allemand', 25 January 2005

${ }^{19}$ Le Monde 'Accord avec la France sur le pacte de stabilité', 27 January 2005

20 The prospects for French preferences being written in to Pact revisions in some form were improved by German preferences aligning with France - notably over a differentiated assessment of spending, the exemption of the costs of re-unification, and of net EU budget contributions, from deficit calculations.

${ }^{21}$ Libération 'Le Pacte de stabilité sur la voie insistante de la réforme’,18 January 2005

${ }^{22}$ Le Monde 'Les Européens s'accordent sur la future réforme du pacte de stabilité', 13 September 2004

${ }^{23}$ The two major agencies Moody's and Standard and Poor's, have consistently assigned France a AAA rating. 


\section{Bibliography}

Andrews, D. (2001), 'Financial Deregulation and the origins of EMU: The French policy reversal of 1983' in Sinclair, T. \& Thomas, K. (eds.) Structure and Agency in International Capital Mobility (Basingstoke; Palgrave), pp. 9-26.

Andrews, D. (1994), 'Capital Mobility and State Autonomy: Towards a Structural Theory of International monetary relations’ International Studies Quarterly 38, pp. 193-218.

Allsopp, C. and Artis, M. (2003), 'The Assessment: EMU Four Years On', Oxford Review of Economic Policy, 19, (1), pp. 12-16.

Begg, I., Hodson. D. and Maher, I. (2003), 'Economic Policy Co-ordination in the EU' National Institute Economic Review 183, pp. 66-77.

Chagny, O. Dupont, G. \& Monperrus-Veroni, P. (2003), 'Politiques Budgétaires en Europe: L’Heure de vérité', La Lettre de L’OFCE, 234, pp. 3-4.

Cameron, D. (1996), 'Exchange Rate Politics in France 1981-83: The Regime Defining Choices of the Mitterrand Presidency' in Daley, T. ed. The Mitterrand Era (London: Macmillan), pp. 56-82

Clift (2005), 'The French Socialists, Dirigisme, and the Troubled Europeanisation of Employment Policy.' in Emmanuel Godin \& Tony Chafer (eds.) The French Exception (Oxford: Berghahn), pp. 106-120.

Clift, B. (2004), ‘The French Model of Capitalism: Still Exceptional?' in Perraton \& Clift (eds.) 'Where Are National Capitalisms Now?' (Basingstoke: Palgrave), pp. 91-110.

Clift, B. (2003a), French Socialism in a Global Era (London: Continuum).

Clift, B. (2003b), 'The Changing Political Economy of France: Dirigisme under Duress' in Ryner, M. \& Cafruny, A. eds. A Ruined Fortress? Neo-Liberal Hegemony and Transformation Europe (New York: Rowman \& Littlefield), pp. 173-200.

Clift, B. (2001), 'The Jospin Way', The Political Quarterly, 72 (2), pp. 170-179.

Clift, B. \& Tomlinson, J. (2004), 'Capital Mobility and Fiscal Policy: The Construction of Economic Policy Rectitude in Britain and France', New Political Economy, 9 (4), pp. 515-537.

Cohen, E. (1995), 'France: National champions in search of a Mission', in Hayward, J. ed.. Industrial Enterprise and European Integration: From National to International Champions in Europe. (Oxford: Oxford University Press), pp. 23-47.

Cohen, E. (1996), La Tentation Hexagonale (Paris: Fayard).

Cohen, B. (1996), 'Phoenix Arisen: The Resurrection of Global Finance', World Politics 48 (January), pp. 268-96.

Cole, A. \& Drake, H. (2000), 'The Europeanisation of the French Polity: Continuity, Change and Adaptation' Journal of European Public Policy, 7 (1), pp. 26-43.

Crawford, M. (1996), One Money for Europe? (Basingstoke: Macmillan).

Creel, J., Dupont, G., Le Cacheux, J., Sterdyniak, H., and Timbeau, X. (2002), 'Budget 2003: Le pécheur non repenti', La Lettre de L'OFCE, 224, pp. 1-4.

Dupont, G. (2000), 'La politique economique', in OFCE, L'Economie francaise 2000. (Paris; La Découverte), pp. 62-72.

Dupont, G. (2001), 'La politique economique' in OFCE, L'Economie francaise 2001. (Paris; La Découverte), pp. 65-75. 
Dyson, K. \& Featherstone, K. (1999), The Road to Maastricht: Negotiating Economic and Monetary Union. (Oxford; Oxford University Press).

Dyson, K. (1980) The State Tradition in Western Europe. (Oxford; Martin Robertson).

Dyson, K (1999a), 'The Franco-German Relationship and economic and monetary union: using Europe to ‘Bind Leviathan’', West European Politics, 22 (1), pp. 25-44.

Dyson, K. (1999b), 'Benign or Malevolent Leviathan? Social Democratic Governments in a Neo-Liberal Euro Area’, Political Quarterly, 70 (2), pp. 195-209.

ECOFIN (2003), 'Economic and Finance Ministers Council Meeting Press Release' Brussels (25 November 2003), Nr. 14492/03.

ECOFIN (2005) 'Improving the Implementation of the Growth and Stability Pact', Report of the extraordinary ECOFIN Council, 20 March 2005, Annex II of European Council 'Presidency Conclusions Brussels European Council 22 and 23 March 2005',http://ue.eu.int/ueDocs/cms_Data/docs/pressdata/en/ec/84335.pdf,7619/1/05REV 1 Eichengreen, B. and Wyplosz, C. (1998), 'The Stability Pact: More than a Minor Nuisance?’ Economic Policy, 26, pp.67-113.

Eijffinger, S. and Hahn, J. (2000), European Monetary and Fiscal Policy (Oxford: Oxford University Press).

European Commission (2004a), Strengthening economic governance and clarifying the implementation of the stability and Growth Pact COM (2004) 581. 3 September 2004. Brussels.

European Commission (2004b), 'The situation in Germany and France in relation to their obligations under the excessive deficit procedure following the judgement of the Court of Justice’, COM (2004) 813. 14 December 2004. Brussels.

European Commission (2002), 'Commission sets out Strategy for Economic Policy Coordination and Surveillance’, Brussels IP/04/35.

European Commission, (2000) The European Economy: Public finances in EMU.

Brussels; European Commission.

European Court of Justice (2004) Press Release No 57/04 13 July 2004 'Judgement of the court of Justice in Case C-27/04'. Brussels.

European Council (2005) 'Presidency Conclusions Brussels European Council 22 and 23 March 2005’,http://ue.eu.int/ueDocs/cms_Data/docs/pressdata/en/ec/84335.pdf, 7619/1/05 REV 1

Gill, S. (1998), 'European Governance and New Constitutionalism: Economic and Monetary Union and Alternatives to Neo-Liberalism in Europe' New Political Economy 3 (1), pp. 5-26.

Halimi, S. Michie, J. \& Milne, S. (1994), ‘The Mitterrand Experience', in Michie, J. and Grieve Smith, J. (eds) Unemployment in Europe. (London; Academic Press), pp. 97-115. Hall, P. (1986), Governing The Economy (Cambridge: Polity).

Hazareesingh, S. (1994), Political Traditions in Modern France, (Oxford: Oxford University Press).

Helleiner, E. (1994), States and the Re-Emergence of Global Finance (Ithaca: Cornell University Press).

Howarth, D. (2004a), 'Breaking the rules: the French reconceptualisation of Economic Government?' Paper presented at the PSA Annual conference, Lincoln, April 2004, pp. 1-35.

(C) Ben Clift, 2006. Department of Politics and International Studies, University of Warwick, UK 


\section{The New Political Economy of Dirigisme}

Howarth, D. (2004b), 'Rhetorical Divergence: Real Convergence? The Economic Policy Debate in the 2002 French Presidential and Legislative Elections' in J. Gaffney (ed.) The French Presidential and Legislative Elections of 2002 (Aldershot: Ashgate), pp. 200-221. Howarth, D. (2002) 'The France State in the Euro Zone' in K. Dyson, ed.. European States and the Euro-Zone, (Oxford: Oxford University Press), pp. 145-172.

Howarth, D. (2001), The French Road to European Monetary Union (Basingstoke: Palgrave).

Jospin, L. (1999), Modern Socialism. (London; Fabian Society).

Jospin, L. (2001), Ma vision de l'Europe et de la mondialisation. Notes de la Fondation Jean-Jaurès, 25, Paris; Plon.

Ladrech, R. (2001), 'Europeanisation and French Social Democracy' Journal of Southern Europe and the Balkans, 3 (1), pp. 37-48.

Lamy, P. \& Pisani-Ferry, J. (2002) 'The Europe We Want' in Jospin, L. My Vision of Europe and Globalization, Cambridge: Polity, pp. 41-149. (Originally published as L'Europe de nos Volontés Notes de la Fondation Jean Jaurès, No. 27, Janaury 2002.

Levy, J. (2005), 'Economic Policy and Policy-Making' in A. Cole, P. Le Galès, and J. Levy (eds.), Developments in French Politics 3, (Basingstoke: Palgrave), pp. 170-195. Levy, J. (2001), 'Social Policy in the Age of High Unemployment', in Guyomarch, A. Machin, H. Hall, P. \& Hayward, J. eds. Developments in French Politics 2. (Basingstoke: Palgrave), pp. 191-210.

Levy, J. (2000), 'France: Directing Adjustment?' in F. Scharpf \& V. Schmidt, Welfare and Work in the Open Economy: Volume Two, (Oxford: Oxford University Press), pp. 337-344.

Lombard, M (1995), 'A Re-examination of the reasons for the failure of Keynesian expansionary policies in France 1981-1983', Cambridge Journal of Economics, 19, pp. 359-372.

Lordon, F. (2001), 'The Logic and Limits of Désinflation Compétitive', in A. Glyn (ed.) Social Democracy in Neoliberal Times (Oxford: Oxford University Press), pp. 110-137. Loriaux, M. (1991), France After Hegemony (Ithaca: Cornell University Press).

Matthieu, C. (2003) 'Politique Economique: La Clé Anglaise', La Lettre de L'OFCE, 233, pp. 1-8.

Mathieu, C. and Sterdyniak, H. (2003), 'Réformer le Pacte de Stabilité: L’Etat du Débat' Revue de l'OFCE, 84, pp. 145-179.

Mathieu, C. and Sterdyniak, H. (2005), 'Pacte de Stabilité: la réforme impossible’ Lettre de l'OFCE, 257, pp. 1-8.

Mayes, D. \& Virén, M. (2004) 'Pressures on the Stability and Growth Pact from asymmetry in policy’, Journal of European Public Policy 11 (5), pp. 781-797.

Moscovici P. (1997), L'Urgence: Plaidoyer pour une autre politique (Paris: Plon).

Muet, P-A. \& Fonteneau, A. (1985), La gauche face A la Crise (Paris: FNSP).

OFCE (2004), 'Meprise sur la reprise: Perspectives pour L'Economie francaise 20042005', Lettre de l'OFCE, 248, pp. 1-8.

OFCE (2003). 'France: Les Illusions Perdus'. Revue de l'OFCE, 85, pp. 157-198

OFCE (2000) L'Economie francaise 2000 (Paris; La Découverte).

OFCE (1999) L’Economie francaise 1999. (Paris; La Découverte).

Palier, B. (2002), Gouverner la sécurité sociale (Paris; Presses Universitaires Francaise). 
Parti Socialiste (1997), Changeons d'Avenir : Nos engagements pour la France (Paris: PS Presse).

Pisani-Ferry, J. (2002), Fiscal Discipline and Policy Coordination in the Eurozone: Assessment and Proposals, Paper prepared for the European Commission President's Group of Economic Analysis.

Polanyi, K. (2001 [1944]) The Great Transformation. (Boston Ma.: Beacon Press).

Ruggie, J. (1982), 'International Regimes, Transactions and Change: Embedded Liberalism in the Post-War Economic Order' International Organization, 36 (2) pp. 379415.

Ryner, M. (2003), 'Disciplinary Neoliberalism, Regionalization, and the Social Market in German Restructuring' in Ryner, M. \& Cafruny, A. eds. A Ruined Fortress? Neo-Liberal Hegemony and Transformation Europe New York: Rowman \& Littlefield, pp. 201-231.

Solbes, P. (2002), 'Budgetary Challenges in the euro area', Communication, SEC 1009/3, 24 September.

Swank, D. (2002), Global Capital, Political Institutions, and Policy Change in Developed Welfare States. Cambridge; Cambridge University Press.

Schmidt, V. (1996), From State to Market? The Transformation of French Business and Government Cambridge: Cambridge University Press.

Schmidt, V. (1997), 'Running on empty: the end of dirigisme in French economic leadership' Modern and Contemporary France 5 (2), pp. 229-241.

Shonfield, A. (1969), Modern Capitalism: The Changing Balance of Public and Private Power (London: Oxford University Press).

Sterdyniak, H. (2004), 'L'Introuvable Réforme fiscale', Lettre de l'OFCE 249, pp. 1-8.

Strauss-Kahn, D. (1999) 'For a European Growth and Employment Pact', 21/4/1999 http://www.finances.gouv.fr/archives/communiques/c9904212.html , Accessed 25/2/2005.

Zysman, J (1983), Government, Markets, Growth: Financial Systems and the Politics of Industrial Change, (Ithaca: Cornell University Press). 